\title{
OVULATION RATE OF FINN-DORSET SHEEP FOLLOWING UNILATERAL OVARIECTOMY OR CHLORPROMAZINE TREATMENT AT DIFFERENT STAGES OF THE OESTROUS CYCLE
}

\author{
R. B. LAND \\ A.R.C., Animal Breeding Research Organisation, \\ West Mains Road, Edinburgh EH9 37Q
}

(Received 6th March 1972)

\begin{abstract}
Summary. Treatment with $10 \mathrm{mg}$ chlorpromazine/kg twice daily for six different 3-day periods during the oestrous cycle (five ewes/group) indicated that the ovulation rate was not depressed by any of the treatments. Treatment during the luteal phase of the cycle, however, raised the subsequent mean ovulation rate slightly ( 2.70 versus 2.27 eggs).

Unilateral ovariectomy on Day 2, 8 or 14 (eleven or twelve ewes/group) did not affect the total number of eggs shed (measured as the number of CL) at the oestrus immediately following ovariectomy.

It was concluded that in the sheep, the number of eggs to be ovulated is finally determined within the 3 days immediately preceding the onset of oestrus.
\end{abstract}

\section{INTRODUCTION}

An understanding of the factors responsible for variation in the number of eggs shed by mammals is partly dependent upon knowledge of the time at which the ovulation rate is determined. This problem can be approached either by attempting to change the ovulation rate by treatments at different times before ovulation, or by studying the growth, maturation and ovulation of specific follicles. The latter approach has recently been applied to the sheep, where follicles were marked with Indian ink at different stages of the oestrous cycle, and their subsequent fate observed (Smeaton \& Robertson, 1971). This technique, however, gives a qualitative assessment of the fate of individual follicles, rather than a direct estimate of the total number of eggs that will subsequently be shed from an ovary subjected to a specific level of gonadotrophic stimulation for different periods of the oestrous cycle. The effects of changes in gonadotrophic stimulation for different phases of the oestrous cycle were therefore studied by attempting to change the endogenous stimulation. The technique of adding hormones such as PMSG was avoided due to the variable response of sheep to this gonadotrophin.

Two methods were used to try to change the stimulus applied to the ovary. Firstly, chlorpromazine was used to suppress the release of gonadotrophins 
(Robertson \& Rakha, 1965) and secondly, the stimulus to a particular ovary was increased by the removal of the other. In both cases, the treatment in question was given at different stages of the oestrous cycle and the subsequent ovulation rate was noted.

\section{MATERIALS AND METHODS}

The experimental work was conducted at the Animal Breeding Research Organization, Dryden Field Laboratory, Roslin, Midlothian, during 1971. FinnDorset females were used throughout.

\section{Chlorpromazine}

Treatment consisted of twice daily intramuscular injections of $10 \mathrm{mg}$ chlorpromazine/ $\mathrm{kg}$ body weight (Largactil: May and Baker; $50 \mathrm{mg} / \mathrm{ml}$ ) for 3 successive days of the oestrous cycle during January. The periods of treatment were Days 0 to 2, 3 to 5,6 to 8,9 to 11,12 to 14 and 15 to 17 ; five ewes were treated for each period and five untreated ewes formed a seventh control group making a total of thirty-five sheep.

Oestrus was determined twice daily by the introduction of a vasectomized ram at 08.00 and 19.00 hours, the chlorpromazine being given when required at 08.30 and 19.30 hours. The detection of oestrus was continued twice daily until the end of the first post-treatment oestrus. All ewes were slaughtered 3 to 13 days after the onset of the post-treatment oestrus and the numbers of CL on both ovaries were recorded. A record of the number of CL on the ovaries of six additional ewes from the same flock was also available, and was pooled with that for the control group. For each of these six ewes, only one heat period was recorded but otherwise they were treated in an identical manner to the control cwes.

\section{Unilateral ovariectomy}

Fifty-four ewes were allocated to this experiment in August and run as a single flock except during surgery or the post-surgical recovery period. Vasectomized rams were introduced on 3rd September and raddled from 6th September. All ewes were examined daily between 08.30 and 10.30 hours for the onset of oestrus (day of onset $=$ Day 0$)$.

A single ovary was removed from eleven ewes at laparotomy performed through a mid-line incision under Nembutal-induced halothane/oxygen anaesthesia at the beginning of the breeding season on 2nd or 3rd September. The ewes were chosen at random, and formed the control group. The ovary to be removed was also chosen at random within the restriction that no more than six ewes had an ovary removed from any one side.

Three further groups were ovariectomized during the breeding season, a single ovary being removed from twelve intact ewes on Day 2, eleven on Day 8 and eleven on Day 14 of the oestrous cycle, and the total number of CL was noted. The ovary to be removed was again chosen at random within the restriction that there was at least one CL on the remaining ovary, and that the number of ewes with ovaries removed from either side should be as nearly balanced as 
possible within the groups. The mid-cycle ovariectomies were conducted between 28th October and 8th November, the ewes showing pretreatment Day 0 between 14th October and 6th November. The remaining ewes which showed irregular oestrous cycles (one) or came into heat on unsuitable days (nine) were discarded from the experiment.

The effects of unilateral ovariectomy were measured in terms of the number of CL following the first oestrus after ovariectomy in the case of the three experimental groups, and compared with both the number of CL observed before ovariectomy in the same group, and the number present in the control group. The second observation of ewes in the three experimental groups was conducted between the 3rd and 15th days after the onset of the first oestrus after ovariectomy, from 5 th to 26th November. The control ewes were examined during the same period, 3 to 15 days after the onset of an oestrous period. The number of $\mathrm{CL}$ on the ovaries present was recorded in the same way as at the time of ovariectomy. The daily detection of oestrus was continued until 1 day before the second examination.

\section{Chlorpromazine}

\section{RESULTS}

The numbers of $C L$ in the ovaries of the control and six experimental groups are given in Table 1 together with the duration of the oestrous cycle covering the period of treatment of the experimental ewes.

Table 1. The number of CL and the duration of the oestrous cycle in ewes given chlorpromazine for different periods during the cycle

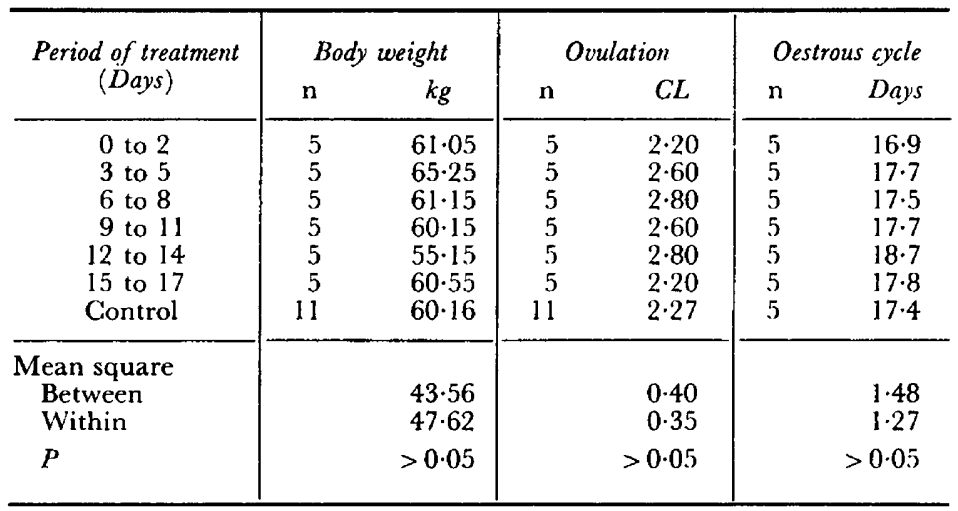

The between and within group mean squares are given from the analyses of variance together with the probability of the observed differences occurring by chance.

Although neither the ovulation rate nor the duration of the oestrous cycle differed significantly between the seven individual groups $(P>0.05)$, the groups treated with chlorpromazine during the luteal phase of the oestrous cycle (i.e. between Days 3 and 14) had a mean ovulation rate approximately 0.5 eggs above that of the controls and the groups treated outside the luteal phase (i.e. 
between Days 15 and 2). A statistical comparison of the control (Mean $=2 \cdot 27$ ), luteal (Mean $=2 \cdot 70$ ) and non-luteal (Mean $=2 \cdot 20$ ) treated groups indicated that the difference between these groups was significant $(P<0.05$, mean square between $=1 \cdot 11$, mean square within $=0.32$ ). A similar comparison of the duration of the oestrous cycle in these three groups showed that this had not been affected by the treatment $(P>0.05$, mean square between $=1.22$, mean square within $=1 \cdot 31$ ).

\section{Unilateral ovariectomy}

The right ovary was removed from five of twelve ewes in the Day-2 group, and six, six and five of the eleven ewes in each of the Day-8, Day-14 and control groups, respectively.

All experimental ewes returned to heat within 19 days of the onset of the oestrus before ovariectomy. The mean duration of the oestrous cycles before treatment and over treatment is given for the three experimental groups in Table 2, together with the duration of the oestrous cycle in the control group

Table 2. The duration of the oestrous cycle of the control group and the experimental group before and over the period of treatment, together with the interval

from ovariectomy to the onset of the next oestrus

\begin{tabular}{l|c|ccc}
\hline & Control & \multicolumn{4}{|c}{ Ovariectomy group } \\
& group & Day 2 & Day 8 & Day 14 \\
\hline Before treatment & $17 \cdot 18^{*}$ & $17 \cdot 36$ & $17 \cdot 40$ & 17.50 \\
$\begin{array}{l}\text { Over treatment } \\
\text { Ovariectomy to } \\
\text { next oestrus }\end{array}$ & - & $17 \cdot 42$ & $17 \cdot 18$ & $17 \cdot 27$ \\
\hline
\end{tabular}

Mean duration of oestrous cycle and mean interval from ovariectomy to onset of next oestrus expressed in days.

* Before the second observation.

before the second observation. The number of days from surgery to the onset of the next oestrus is also given in Table 2, as an estimate of the time during which ovarian compensation was able to take place. The interval ranged from 15.4 days, i.e. almost all the oestrous cycle, to $3 \cdot 3$ days, i.e. less than one quarter of the cycle.

The removal of one ovary clearly had very little effect on the duration of the oestrous cycle in which it occurred. The single ovary remaining in each of the thirty-four ewes examined following the post-surgical oestrus ovulated at the normal interval after the preceding oestrus, as did all eleven ovaries in the control group, compared to fifty-one of the sixty-eight ovaries examined in the thirtyfour animals of the three experimental groups at the time of ovariectomy. In this respect, therefore, ovarian compensation appeared to be complete in all of the groups.

The number of ewes and ovaries with ovulations, and the number of ovulations/ewe ovulating are given in Table 3. All four groups had an average of 
Table 3. The incidence of ovulation and the mean number of eggs shed before and after unilateral ovariectomy of ewes at different stages of the oestrous cycle

\begin{tabular}{|c|c|c|c|c|}
\hline & \multirow{2}{*}{$\begin{array}{c}\text { Control } \\
\text { group }\end{array}$} & \multicolumn{3}{|c|}{ Ovariectomy group } \\
\hline & & Day 2 & Day 8 & Day 14 \\
\hline No. of ewes & 11 & 12 & 11 & 11 \\
\hline $\begin{array}{l}\text { Before ovariectomy } \\
\text { Ewes with an ovulation } \\
\text { Ovaries with an ovulation } \\
\text { Ovulations per ewe ovulating }\end{array}$ & $\begin{array}{r}6 / 11 \\
11 / 22 \\
2.33\end{array}$ & $\begin{array}{r}12 / 12 \\
15 / 24 \\
2 \cdot 67\end{array}$ & $\begin{array}{r}11 / 11 \\
15 / 22 \\
2 \cdot 27\end{array}$ & $\begin{array}{r}11 / 11 \\
21 / 22 \\
2 \cdot 36\end{array}$ \\
\hline $\begin{array}{l}\text { After ovariectomy } \\
\text { Ewes with an ovulation } \\
\text { Ovaries with an ovulation } \\
\text { Ovulations per ewe ovulating }\end{array}$ & $\begin{array}{r}11 / 11 \\
11 / 11 \\
2 \cdot 27\end{array}$ & $\begin{array}{r}12 / 12 \\
12 / 12 \\
2 \cdot 42\end{array}$ & $\begin{array}{r}11 / 11 \\
11 / 11 \\
2.18\end{array}$ & $\begin{array}{r}11 / 11 \\
11 / 11 \\
2 \cdot 45\end{array}$ \\
\hline
\end{tabular}

approximately $2.25 \mathrm{CL}$ at the time of the second observation, the group means being very little different either from each other or from themselves at the previous observation. The number of eggs shed changed by $-0.25 \pm 0.13$, $-0.09 \pm 0.16$ and $+0.09 \pm 0.16$ in the 2-, 8- and 14-Day groups, respectively, a mean decline of only $3 \%$ compared to an expected decline of $50 \%$ in the absence of ovarian compensation. In terms of the number of eggs shed/ewe, ovarian compensation was complete in all groups.

\section{DISCUSSION}

The removal of one ovary at different stages of the oestrous cycle has demonstrated conclusively that the ovulation rate of the sheep is not determined irreversibly before Day 14 of the oestrous cycle. Not only do 'ovarian follicles appear to have the capacity to grow rapidly from $2 \mathrm{~mm}$ in diameter to a follicle ripe for ovulation within the space of 2 to 3 days' (Smeaton \& Robertson, 1971 ), but also the number of follicles which mature is unaffected by a $50^{\circ}$, reduction in the number available 3 days before the onset of oestrus. The shortterm nature of ovarian compensation in the sheep is apparently similar to that observed for the hamster (Greenwald, 1962) in which the critical time was found to be mid-way through the 4 -day oestrous cycle $(09.00$ hours, Day 3$)$. It is also compatible with the effects of re-feeding sheep at different stages of the oestrous cycle (Lamond \& Bindon, 1969), if one assumes that re-feeding does not have an immediate effect. These results also confirm the finding of Sundaram \& Stob (1967) that ovarian compensation in the sheep leads to the maintenance of the normal ovulation rate, compared to the wide range from no compensation to a factor of 2.9 as reviewed for other species (McLaren, 1966). Furthermore, the rapid compensation applies to both ovulation and luteinization as well as to follicular development as studied by Mallampati \& Casida (1970).

The increased ovulation rate of the Finn-Dorset ewes following treatment with chlorpromazine during the luteal phase of the oestrous cycle was unexpected, but this phenomenon is apparently most likely to arise from a reduc- 
tion in the mid-cycle release of gonadotrophin which is compensated for by an increased release later in the oestrous cycle and closer to the time at which the ovulation rate is coordinated. Under such circumstances, however, it is difficult to understand the present failure to observe a response to treatment close to the time of ovulation. This failure to respond is even more surprising in view of the observation of Robertson \& Rakha (1965) that a single dose of $12 \mathrm{mg} / \mathrm{kg}$ (only $2 \mathrm{mg} / \mathrm{kg}$ greater than the present doses) at the onset of oestrus was sufficient to block ovulation in five Cheviot ewes. Similarly, Buttle \& Robertson (1967) found that the onset of oestrus in Cheviot ewes was blocked by $12 \mathrm{mg}$ chlorpromazine $/ \mathrm{kg}$ followed by $4 \mathrm{mg} / \mathrm{kg}$ every $6 \mathrm{hr}$, whereas the display of oestrus and the duration of the cycle were unaffected in the present experiment. The absence of an effect of chlorpromazine on the secretion of progesterone by the CL of hysterectomized ewes was taken to indicate that prolactin rather than LH is luteotrophic in the sheep (Coudert \& Short, 1968) but unfortunately the breed of ewe was not specified. It is possible, therefore, that the response to chlorpromazine is partly breed-dependent and, in such a situation, that the relative insensitivity of the Finn-Dorset ewes is due to their higher ovulation rate being associated with greater gonadotrophic stimulation (as postulated for the Finnish Landrace, see Land, 1971), arising from a reduced sensitivity to inhibitory mechanisnss.

It may be concluded from both parts of this study that the ovulation rate of the sheep is finally coordinated around the time of the regression of the CL, and certainly within 3 days of the onset of oestrus. This would indicate that, if a causal relationship between gonadotrophic activity and ovulation rate exists, it will most probably be found during the few days before ovulation. Land, Crighton \& Lamming (1972), however, observed a difference in the LH potency of the pituitary in high and low fertility breed types at mid-cycle rather than around the time of oestrus, and it is therefore possible that although the ovulation rate of the sheep is not finally determined until the last 3 days of the oestrous cycle, the normal ovulation rate is determined somewhat earlier.

\section{ACKNOWLEDGMENTS}

I wish to thank Miss M. Fordyce, Mr R. D. Preece and Mr A. G. Wheeler for surgical assistance, and the Dryden sheep experimental staff for the care of the animals and detection of oestrus.

\section{REFERENGES}

Buttle, H. R. L. \& Robertson, H. A. (1967) The pharmacological blockade of the initiation but not the maintenance of sexual receptivity in the ewe. F. Endocr. 39, 115.

Coudert, S. P. \& Short, R. V. (1968) The effects of chlorpromazine treatment on the secretory activity of corpora lutea in hysterectomized sheep. 7. Reprod. Fert. 16, 151.

Greenwald, G. S. (1962) Temporal relationships between unilateral ovariectomy and the ovulation response of the remaining ovary. Endocrinology, 71, 664 .

LAMond, D. R. \& Bindon, B. M. (1969) Effect of nutrient intake on ovulation in mice and sheep. Biol. Reprod. 1, 264.

LAND, R. B. (1971) The incidence of oestrus during lactation in Finnish Landrace, Dorset Horn and Finn-Dorset sheep. 7. Reprod. Fert. 24, 345.

Land, R. B., Crighton, D. B. \& Lamming, G. E. (1972) Gonadotrophin content of the pituitaries of sheep of differing fertility at three stages of the ocstrous cycle. F. Reprod. Fert. 30, 313. 
McLaren, A. (1966) Regulation of ovulation rate after removal of one ovary in mice. Proc. R. Soc. B, $166,316$.

Mallampati, R. S. \& CAsida, L. E. (1970) Ovarian compensatory hypertrophy following unilateral ovariectomy during the breeding season in the ewe. Biol. Reprod. 3, 43.

Robertson, H. A. \& RAKHA, A. M. (1965) The timing of the neural stimulus which leads to ovulation in the sheep. 7. Endocr. 32, 383.

Smeaton, T. G. \& Robertson, H. A. (1971) Studies on the growth and atresia of Graafian follicles in the ovary of the sheep. 7. Reprod. Fert. 25, 243.

Sundaram, S. K. \& Stoв, M. (1967) Effect of unilateral ovariectomy on reproduction and induced ovulation in ewes. J. Anim. Sci. 26, 374. 